\title{
NOTES
}

\section{DISCRIMINATORY ENFORCEMENT OF FAIR TRADE PRICES: THE PROBLEMS AND REMEDIES UNDER STATE AND FEDERAL LAWS}

FAIR Trade statutes in forty-five states permit the manufacturer of a brandnamed product to fix the retail price at which his product may be sold. ${ }^{1}$ Enforcement of fair trade contracts, exempted from the operation of the federal antitrust laws by the Miller-Tydings and McGuire Acts, ${ }^{2}$ is generally left to private litigants. ${ }^{3}$ Normally, private enforcement takes the form of

1. $1 \mathrm{CCH}$ Trade Reg. Rep. $\| 3003$ (1955). E.g., "No contract relating to the sale or resale of a [brand-named] commodity . . . which is in fair and open competition with commodities of the same general class produced by others shall be deemed in violation of any law [by reason of $].$. the following provisions ... :

"(a) That the buyer will not resell such commodity except at the price stipulated by the vendor;

"(b) That the vendee or producer require any dealer to whom he may resell such commadity to agree that he will not, in turn, resell except at [the stipulated price]. ..." N.Y. Gen. Bus. LaW $\$ 369$-a (Feld-Crawford Act) reprinted in 2 CCH Trade REG. Rep. If 13520.01 (10th ed. 1954).

While they are substantially similar, the laws vary as to whether distributors, as well as owners of the brand name, may establish fair trade agreements, and whether absolute as well as minimum prices may be established. See 2 id. If 10000-15585. For a comparison by chart of the fair trade laws, see 1 id. T 3003 (1955). For discussions of fair trade in gencral, consult Report of tae FTC on Resale Price Maintenance (1945) (hereinafter cited as FTC Fair Trade Report) ; Grether, Price Control Under Fatr Trade Lrigislation (1939); Weigel, The Fatr Trade Acts (1938).

2. The Miller-Tydings Amendment to the Sherman Act exempted agreements that were legal under the state fair trade laws from the federal price-fixing laws. 50 STAT. 693 (1937), 15 U.S.C. $\$ 1$ (1952). However, in Schwegmann Bros. v. Calvert Distillers Corp., 3\$1 U.S. 3S4 (1951), the Supreme Court held that Miller-Tydings exempted enforcement of fair trade contracts only against parties to those contracts ("signers"). See Comment, The Schwegmam Case and Fair Trade: An Obituary?, 61 YALE L.J. 381 (1952).

The McGuire Act was passed to broaden the antitrust immunity of resale price maintenance contracts by validating state "nonsigner" clauses. 66 STAT. 632, 15 U.S.C. $\S$ 45 (1952); see Schwegmann Bros. v. Eli Lilly \& Co., 205 F.2d 788 (5th Cir.), cert. dcnicd, 346 U.S. 856 (1953) (constitutionality upheld). These clauses ordinarily provide that "willfully and knowingly advertising ... or selling any commodity at less than the price [prescribed in fair trade contracts is actionable by 'any person damaged thereby'] ... whether the person so advertising . . or selling is or is not a party to such contract [or agreement]. . .." See, e.g., N.Y. GEN. Bus. LAw $\$ 369-\mathrm{b}$. Several state courts have held such nonsigner provisions unconstitutional. See note 34 infra.

3. The state laws typically provide that an action may be brought against violators by "any pcrson damaged thereby." In addition, some states authorize government officials tu enforce fair trade contracts. IDAHo CoDE ANN. $\$ 48-310$ (Supp. 1955) (Governor); Minn. Stat. Ann. $\$ 362.14$ (West Supp. 1954) (Commissioner of Business Research and 
injunction suits against retailers who have violated the fair trade law, brought either by other retailers or by the fair trading manufacturer. ${ }^{4}$ Recently, increasing criticism has focused on the effects of the sporadic and discriminatory enforcement practices of some manufacturers. ${ }^{5}$ For fair trade legislation seeks to achieve three policy goals: 1) to enable a manufacturer to protect his "good will" interest in a brand-named product; ${ }^{6} 2$ ) to protect the small retailer from the price competition of mass distributors ; and 3 ) to prevent undue concentration in the channels of distribution. ${ }^{8}$ Discriminatory enforcement conflicts with all three policies.

Development); UTAH Code ANn. \$ 13-2-11 (1953) (similar); Wyo. Conp. Stat. § 39-308 (1945) (state and county prosecutors).

4. Actions for damages are unusual because of the difficulty of proving that financial losses are causally related to a violation of the fair trade law. WEIGEL, op. cit. supra note 1, at 78; Zorn \& FeldMan, Business Under the New Price Laws 311 (1937).

Originally there was some question whether a retailer was a "person damaged" within the meaning of the fair trade statute. This stemmed from the early belief that the purpose of resale price maintenance was to protect the "good will" property interest of the producer in the fair traded commodity. See note 6 infra. However most courts have allowed suits by retailers. Note, 36 CORN. L.Q. 781, $785 \mathrm{n} .18$ (1951) (collecting New York citations).

5. E.g., N.Y. Times, Oct. 19, 1955, p. 27, col. 1; id., Oct. 16, 1955, § X, p. 1, col. 2; Corey, Fair Trade Pricing: A Reappraisal, Harv. Bus. Rev., Sept.-Oct. 1952, pp. 47, 61; Hearings on H.R. 5767 (McGuire Bill) Before the Senate Committee on Interstate and Foreign Commerce, 82d Cong., 2d Sess. 267-69, 287 (1952) (hereinafter cited as Senate Hearings on H.R. 5767) ; Hearings Before the Antitrust Subcommittee of the House Committee on the Indiciary on Resale Price Maintenance, 82d Cong., 2d Sess. 174 (1952) (hereinafter cited as House Antitrust Subcommittce Hearings).

6. It is contended that widespread price-cutting of a manufacturer's brand-named product will shake consumer confidence in the particular brand. MIILLER, UNFarR ConpetrTton 231-32 (1941) ; Fulda, Resale Price Maintenance, 21 U. CHI. L. REv. 175, 184-86 (1954). When the manufacturer's product is used as a loss leader, i.e., sold below a normal markup in order to attract customers who may buy other products once they are in the store, it is argued that these consquences are accelerated. See Housc Antitrust Subcommittee Hearings, supra note 5, at 171, 231, 253, 260-62, 494, 564, 570, 786. The Supreme Court sustained the constitutionality of state fair trade legislation upon a rationale of protecting the manufacturer's property interest in his brand name. Old Dearborn Distributing Co. v. Seagram-Distillers Corp., 299 U.S. 183, 193 (1936). However, it has been suggested that fair trade is not really necessary to protect the good will of the manufacturer's brand name. Yaniex, The Economics of Resale Price Maintenance 63-64 (1954); Corey, supra note 5, at 60; Schachtman, Resale Price Maintenance and the Fair Trade Lazes, 11 U. PrTr. L. REv. 562, 577 (1950).

7. Small retailers are the real beneficiaries of fair trade legislation. Eli Lilly \& $\mathrm{Co}$. v. Schwegmann Bros., 109 F. Supp. 269, 272 (E.D. La.), aff'd, 205 F.2d 788 (5th Cir.), cert. denied, 346 U.S. 856 (1953); FTC FaIr TRade Report xavi-xuvii, 52-56; Stocking \& Watkins, Monopoly and Free Enterprise 328-29 (1951); Fulda, supra note 6, at 180-84. Under the mantle of fair trade, retailers selling at the fixed price are safeguarded from the price competition of mass distributors who sell at lower profit margins. See, generally, GreTher, op. cit. supra note 1, at 225-35; KapLAN, SMALL BusnNess: Its Place and Problears 198 (1948); cf. FTC, Final Report on the Chain Store Investigation, S. Doc. No. 4, 74th Cong., 1st Sess. (1934).

8. The last three decades have been marked by an increasing concentration of distributive facilities in the hands of a few retailers. See, generally, FTC Chain SToRE 
Discriminatory enforcement ${ }^{9}$ is extremely profitable to the fair trading manufacturer. $\mathrm{He}$ is able to distribute his product through a large number of retail outlets, because fair trade ordinarily assures the retailer of a secure margin of profit. ${ }^{10}$ Wide distribution tends to increase sales. ${ }^{11}$ And when a product is widely distributed at a fair trade price, the consumer tends to identify the value of the product with the price at which it is sold. ${ }^{12}$ When he enforces fair trade prices against retailers but not against larger discount houses, a manufacturer is generally able to maintain these benefits of fair trade. ${ }^{13}$ At the same time, he is able to take advantage of additional benefits ordinarily inconsistent with the operation of and the policies behind fair trade: he obtains added revenue, at diminishing costs, ${ }^{14}$ from cut-price sales to the

REPORT, ap. cit. supra note 7, passin; Silberman, Retailing: It's a New Ball Game, Fortune, Aug. 1955, pp. 78, 79. More than $50 \%$ of retail distribution is handled by about 400 retailers. Weiss, Mass Miarketing to the "400" Mass Retarlers 3 (1950). The hair trade laws may be supported as a means of preventing increased monopoly of distribution by the use of loss leaders, most profitably used by large distributors. KaPLAN, op. cit. supra note 7, at 199-200; Burns, The Antitrust Laws and the Regulation of Price Comptition, 4 Law \& Contemp. Prob. 301, 307 (1937); Fulda, supra note 6, at 198; ste note 24 infra. In this respect, fair trade complements the policy behind the RobinsonPatman Act, 49 Star. 1526 (1936), 15 U.S.C. $\$ 13$ (1952). See House Select Committee on Small Eusiness, H.R. REP. No. 1292, 82d Cong., 2d Sess. $44-47$ (1952).

9. The following discussion is concerned with both discriminatory and ineffective cuforcement. The consquences of ineffective enforcement may be the same to a particular retailer as the consequences of discriminatory enforcement. The terms will be used interchangcably and without regard to the bona fides of the manufacturer.

10. Covrs, Probleas of Suall Business 191 (TNEC Monograph No. 17, 1941); MinLLer, ap. cit. supra note 6, at 232; WeIGEL, op. cit. supra note 1, at 11-17.

In deciding whether or not to fair trade his brand-named product, the manufacturer must evaluate the relative advantages of different channels of distribution. See Corey, suts ra note 5 , at 51,62 . Because it is risky to become dependent on only a single distributive channel, the manufacturer may seek to exploit different channels simultaneously. Rowe, Price Discrimination, Competition and Confusion: Another Look at RobinsonPatman, co YaLe L.J. 929, 934-35 (1951).

11. Intensive distribution will increase volume by facilitating consumer "impulse buying." Corey, supra note 5 , at 51 .

12. Id. at 52; House Antitrust Subcommittee Hearings, supra note 5, at 344-45. This price-value identification has been valuable to the discount houses, which capitalize on the consumer's sense of getting a "bargain." This indirectly benefits the manufacturer also. See notes $15-18$ infra and accompanying text.

13. See text at note 18 infra. This will be true only so long as the profits from discriminatory cnforcement continue to offset the concomitant diminishing of fair trade benefits. Thus, if unchecked price competition persuades many small retailers to drop his product, or to "push" it less actively than other brands, the manufacturer will lose the advantages of intensive distribution. And, as price-cutting becomes widespread, the effects on the manufacturer's brand name and the price-identification of his product will be increasingly injurious.

14. Discriminatory enforcement would yield greater profit per unit sale, since the manufacturer's distribution costs are proportionally decreased by increased volume through mass distributors. WeIss, op. cit. supra note 8, at 356; Silberman, supra note 8, at 178 . 
marginal customers attracted to discount houses. ${ }^{15}$ The advantages of discriminatory enforcement have become increasingly significant with the phenomenal growth of the discount house, ${ }^{16}$ which has now appropriated fifteen per cent of the retail market. ${ }^{17}$ Moreover most retailers, dependent on nationally-advertised brands, will be reluctant to drop a fair traded product even though discriminatory enforcement enables the discount house to divert many of their customers. ${ }^{18}$

The retailer injured by discriminatory enforcement does not have adequate judicial remedies. Under present state laws it is unlikely that he will be able to obtain what would ordinarily be his most effective remedy: an injunction requiring the manufacturer affirmatively to assume full responsibility for plenary enforcement of fair trade agreements. ${ }^{19}$ The next most effective remedy, a declaratory judgment determining the relative rights of the retailer and the manufacturer, will not be permitted unless the retailer joins as "neces-

15. Manufacturers soon realized that fair trade may reduce the volume of goods sold through large dealers without a compensating increase in goods sold through small retailers. Converse \& Huegr, Elemients of Marketing 166-67, 170 (3rd ed. 1947); Cover, op. cit. supra note 10, at 200-01; MIILLR, op. cit. supra note 6, at 260. Discriminatory enforcement enables the manufacturer to permit discount houses to bring new, "marginal" customers, i.e., those unwilling to pay the fair trade price, into the market.

16. Although the fixed margins under resale price maintenance have benefited the discount houses, fair trade is not the sole explanation for their development. Hollander, The Discount House, 18 J. Marketrang 57 (1953). The discount house has dramatized the significant changes occurring in retail distribution. The emphasis on national advertising and self-service retailing has transfered typical retailing functions backward to the manufacturer or forward to the consumer. These developments have brought relentless pressure to bear on retail margins. Silberman, supra note 8 , at 79-80;20 ConsuMarers REP. 339, 341 (1955). The discount house has generally flourished while paying full manufacturer prices for its wares; the lower prices represent a lower retail margin. Ibid.; Note, 64 Harv. L. Rev. 1327, 1334 (1951). The discount house accepts the fines which are imposed for fair trade violations as one cost of a profitable business. Brecher, The Revolt Against Price Fixing, 15 Consumers Rep. 218 (1950).

17. United States Chamber of Commerce Report, cited in Silberman, supra note 8 , at 80 . This 1954 study indicated that discount houses did an annual business of $\$ 25$ billion. Their market share in large cities may run as high as $75 \%$ in certain appliances. Ibid. And see 20 Consungrs REP. 339 (1955) ; House Antitrust Subcomnittee Hearings, supra note 5 , at 478 .

18. FTC Fair Trade Report 7; Kaplan, Salall Business: Its Place and Problems 188 (1948); Mrller, Unfair Competition 259 (1941); Stocking \& Watkins, Monopoly and Free Enterprise 328-29 (1951).

19. Most state statutes make selling at less than the fair trade price an actionable offense, but do not make it illegal for the manufacturer to allow such underselling. E.g., N.Y. GEN. Bus. LAw $\$ 369-\mathrm{b}$. And if by inference the court found that discriminatory enforcement was actionable, it might still be reluctant without statutory authority to grant "affirmative" rather than "prohibitory" orders. See McClintack, EQuiry $\$ 15$ (2d ed. 1948); WaLsh, EQuiTY $\$ 66$ (1930). However the modern tendency seems to be to grant affirmative decrees more freely. And decrees that are affirmative in effect may be couched in negative terms. McClintock, op. cit. supra. Thus, the manufacturer might be enjoined from discriminating. 
sary parties" all other merchants subject to the fair trade law. ${ }^{20}$ And even then, declaratory relief may be denied on the ground that the retailer will have an "adequate" remedy if and when he needs it. ${ }^{21}$ Thus the retailer has been compelled to protect himself by a costly series of injunction suits brought against price-cutting competitors as each violation occurs. ${ }^{22}$

Moreover, the retailer must keep his own hands "clean" while he is seeking these remedies. ${ }^{23} \mathrm{He}$ must maintain his prices at a static fair trade level while his business is being diverted to the price-cutting merchants whom he is prosecuting for violations of the fair trade laws. Thus the retailer is placed in an untenable position. For it may be commercial suicide to maintain his fair trade prices while waiting for judicial relief. But if he lowers his price in an attempt to meet the competition of the discount house, ${ }^{24}$ he subjects himself to an injunction suit brought either by competing retailers or by the fair trading manufacturer. ${ }^{25}$ The manufacturer would probably be precluded

20. Weissbard v. Potter Drug \& Chemical Corp., 6 N.J. Super. 451, 69 A.2d 559 (Ch. 1949) ; Stockman v. Wilson Distilling Co., 175 Misc. 314, 23 N.Y.S.2d 510 (Sup. Ct. 1940). Otherwise, the courts argued, the declaratory judgment would not determine with finality all the jural relations attaching to the fair trade agreements; price cutting by plaintiff would still be actionable by other retailers.

21. Weissbard v. Potter Drug \& Chemical Corp., 6 N.J. Super. 451, 456, 69 A.2d 559, 561 (Ch. 1949) (dictum). The "adequate" remedy the court referred to was that the retailer may plead discriminatory enforcement as a bar to an injunction suit by the manufacturer. See note 26 infra. However, denial of relief on this ground is antithetical to the policies underlying the development of the declaratory judgment, which seeks to provide the prospective litigant with an alternative to acting at the peril of costly and uncertain litigation. BoRChard, DeCLARATORY JUdGMents 927-37 (2d ed. 1941).

22. Aside from the expense and inconvenience of protracted litigation, the retailer might hesitate to pursue this course for fear of acquiring the community reputation of being a "high price" store which seeks to prevent consumers from obtaining lower prices. Senate Hearings on H.R. 5767, supra note 5, at 272; Fogel v. Bolet, 194 Misc. 1019, 1022, 91 N.Y.S.2d 642, 646 (Sup. Ct. 1949) (dictum).

23. E.g., Prodes v. Lythe, CCH Trade REg. Rep. (1955 Trade Cas.) $\{67699$ (N.Y. Sup. Ct. Jan. 12, 1955) ; Fogel v. Bolet, 194 Misc. 1019, 91 N.Y.S.2d 642 (Sup. Ct. 1949); Weisstein v. Corbyon Liquor Stores, Inc., 174 Misc. 1075, 22 N.Y.S.2d 510 (Sup. Ct. 1940). Contra, Librandi v. Berner's Pharmacy, Inc., CCH Trade Reg. Rep. (1955 Trade Cas.) I 67966 (N.Y. Sup. Ct. Jan. 24, 1955); see Klein v. Mittman, CCH Trade REg. REP. (1955 Trade Cas.) $\int 68030$ (N.Y. Sup. Ct. April 22, 1955) (injunction granted although one of three plaintiffs was violating fair trade prices).

24. Of course, the retailer may not be able to lower his price sufficiently to meet the competition of the mass distributor. This would particularly be true if the large retailer were using the fair traded item as a loss leader. See, generally, Grether, PrICE ConTrol Under FaIr Trade Legislation 199-225 (1939); Miller, Unfair ContPettTion 249-58 (1941) ; Comment, 57 Y ALE L.J. 391 (1948); note 6 supra. Loss leaders are best utilized by large stores with diversified stock. Small retailers with less diversified lines of commodities cannot operate on this basis. House Antitrust Subcommittee Hearings, supra note 5, at 218, 260; Clark \& Ciark, Princtples of Marketing 695 (3d ed. 1942); Edwakds, Maintaining Competition 68 (1949) ; Kaplan, op. cit. supra note 18, at 199200. Nor can the small retailer advertise on the scale necessary to make the loss leader successful. House Antitrust Subcommittee Hearings, supra, at 224-25; Converse \& Huegy, Elements of Marketing 165 (3d ed. 1947).

25. See notes $3,4,19$ supra. 
from obtaining equitable relief because of his discriminatory enforcement. ${ }^{20}$ But a suit brought by retailers who have maintained fair trade prices could not be defeated unless the defendant retailer proved that price-cutting was so widespread that fair trade had in fact been "abandoned." 27

Dissatisfied with existing remedies under state laws, fair trade advocates have turned to the Federal Trade Commission for relief. An association of retail jewelers notified the Commission that fair trade was being discriminatorily enforced in their industry. ${ }^{28}$ The FTC refused to investigate their charges, primarily on the ground that the McGuire Act only exempted fair trade agreements from the federal price-fixing laws; it did not empower federal agencies to compel enforcement of the agreements. ${ }^{29}$ The Commission further stated that FTC action was unnecessary because the retailers already had adequate remedies under state fair trade laws. ${ }^{30}$

26. Inadequate or discriminatory enforcement by the manufacturer is a "clean hands" defense. See General Elec. Co. v. Federated Dep't Stores, Inc., CCH Trade Reg. Rep. (1.955 Trade Cas.) ๆ 68098 (E.D. Wis. July 20, 1955) ; Parker Pen Co. v. E. J. Korvette Co., CCH Trade Reg. Rep. (1955 Trade Cas.) I 68025 (S.D.N.Y. April 16, 1955); Westinghouse Elec. Corp. v. Charles Appliances, Inc., 1954 Trade Cas. If 67685 (N.Y. Sup. Ct.).

The elements of an adequate, non-discriminatory enforcement program are not prescribed by the fair trade statutes. In the absence of legislative guidance the courts have generally agreed that an injunction will not be granted if there has been a completc lack of enforcement. Victoria Silk Press, Inc. v. E. J. Korvette Co., CCH TRADE REG. ReP. (1955 Trade Cas.) đI 67948 (N.Y. Sup. Ct. Dec. 23, 1954) ; Automotive Elec. Serv. Corp. v. Times Square Stores Corp., 175 Misc. 865, 24 N.Y.S.2d 733 (Sup. Ct. 1940); Ray Kline, Inc., v. Davega-City Radio, Inc., 168 Misc. 185, 4 N.Y.S.2d 541 (Sup. Ct. 1938). However, it is not necessary to sue all violators simultaneously. Revere Copper \& Brass Co., 127 F. Supp. 739 (D. Conn. 1954) ; Calvert Distilling Co. v. Gold's Drug Stores, 123 N.J. Eq. 458, 198 A.2d 536 (Ch. 1938) (one suit may be a warning to other offenders); General Elec. Co. v. Crown Nat'l Corp., 1950-51 Trade Cas. II 62614 (N.Y. Sup. Ct. 1950). Few courts have attempted to set forth the standards which a court will demand before granting an injunction in intermediate cases. With only general standard: as guides, the enforcement program of a single manufacturer has been held adequate by some courts and inadequate by others. Compare General Elec. Co. v. R. H. Macy \& Co., 199 Misc. 87, 103 N.Y.S.2d 440 (Sup. Ct. 1951) (injunction granted on basis of vigorous enforcement program), with General Elec. Co. v. Federated Dep't Stores, Inc., supra (injunction denied on basis of ineffective enforcement program).

27. Pimsler v. Angert, CCH Trade Reg. Rep. (1955 Trade Cas.) I 68049 (N.Y. Sup. Ct. May 11, 1955) ; Fisher v. Rothberg, CCH Trade Reg. Rep. (1955 Trade Cas.) $\int 68029$ (N.Y. Sup. Ct. Mar. 4, 1955). The defendant retailer may have added difficulty if he encounters judicial reluctance to impose the burden of comprehensive enforcernent on a plaintiff retailer. Fogel v. Bolet, 194 Misc. 1019, 1922, 91 N.Y.S.2d 642, 646 (Sup. Ct. 1949) (dictum).

28. The request of the retailer association is briefly summarized in an FTC statement of policy accompanying its refusal to investigate. $1 \mathrm{CCH}$ TRADE REG. REP. If 3020.90 (Feb. 21, 1955). The allegations of the petitioners were in general terms only.

29. The FTC stated that the McGuire Act "does not impose on the Commission any affirmative regulative duties; it does not in terms prohibit any practice nor require the Commission to take corrective action towards proscribed activities. ..." $1 \mathrm{CCH} \mathrm{T}_{\mathrm{RADE}}$ REG. REP. \ 3020.90, at 4130 (Feb. 21, 1955). See notes 2 supra, 36 infra.

30. 1 CCH Trade REg. Rep. If 3020.90, at 4130-31 (Feb. 21, 1955). 
The FTC dismissed the problem of discriminatory enforcement too readily. It is clear that the retailers did not have adequate remedies. ${ }^{31}$ And the Commission's failure to act was not based upon a lack of jurisdiction. ${ }^{32}$ Rather, it was premised on two conclusions: 1) that fair trade is anticompetitive and should not be encouraged; and 2) that any positive action the FTC took would require enforcement of fair trade contracts and would thereby encourage fair trade. ${ }^{33}$ The first premise certainly is arguable. Fair trade has been criticized by courts ${ }^{34}$ and commentators ${ }^{35}$ on economic and constitutional

31. See notes 19-27 sufra and accompanying text.

32. It seems clear that the FTC could have proceeded against the discriminatory enforcement under $\$ 5$ of the Federal Trade Commission Act, 38 Stat. 719 (1914), as amended, 15 U.S.C. $\$ 45$ (a) (1952), which broadly proscribes all "unfair methods of competition" in commerce. See Comment, The "New" Federal Trade Commission and the Enforcement of the Antitrust Laws, 65 YaLe L.J. 34 n.1 (1955); note 37 infra and accompanying text. The FTC recognized that action might have been warranted if the juwelry rctailers did not already have "adequate" remedies. $1 \mathrm{CCH}$ TRADE REG. REP. If 3020.90, at 4130 (Feb. 21, 1955). And certainly the McGuire Act, which exempts fair trade arreenents from federal prosecution under price-fixing laws, does not provide a blanket immunity of fair trade from action by federal authorities. See United States v. Franlfort Distillers, Inc., 324 U.S. 293 (1945); notes 2 supra, 38, 42 infra. Nevertheless, some advocates of fair trade have insisted, perhaps with a view to encouraging remedial legislation, that the FTC is without jurisdiction to prevent discriminatory enforcement of fair trade. Sce American FaIr Trade Councth, Questions and ANswers about the Fair-Play AMrendisent, Question 9. Consequently, they have introduced a "Fair Play" bill to the Senate which would expressly authorize the FTC to proceed against any manufacturer who "willfully or knowingly" sells a fair traded product to a price-cutter. S. 2055, 84 th Cong., 1st Sess. (introduced May 24, 1955). This bill would go further, however, than correcting the inaction of the FTC in the jewelry retailer case: it would subject the manufacturer to injunction proceedings brought by fair trading retailers in federal coutrts and under fediral law. Id. $\$ 7$.

33. This is borne out by the Commission's statement at the end of its letter that it "must act in the public interest, to affirm, whenever possible, the basic competitive rationale of our free enterprise system." 1 CCH TRADE REg. REP. $\uparrow$ 3020.90, at 4131 (Feb. 21, 1955). See also Doubleday and Co., Docket No. 5897, 3 id. \2 25634, at 35680 (FTC Sept. 2, 1955) (dissenting opinion).

34. In ten states courts have declared fair trade prices unenforceable against nonsigners. The principal constitutional argument is that the non-signer provision in the state fair trade laws is an unconstitutional delegation of legislative power to private individuals. See, c.g., Union Carbide \& Carbon Corp. v. White River Distributors, Inc., 275 S.W.2d 455 (Ark. 1955) ; McGraw Elec. Co. v. Lewis \& Smith Drug Co., 159 Neb. 703, 68 N.W.2d 608 (1955) ; Rogers-Kent, Inc. v. Westinghouse Elec. Corp., CCH TRADE REg. REP. (1955 Trade Cas.) If $\epsilon 8084$ (S.C. County Ct. July 7, 1955) ; Bargain Barn, Inc. v. Arvin Industries, Inc, CCH Trade Reg. Rep. (1955 Trade Cas.) I 68074 (Ind. Super. Ct. June 17, 1955).

35. Principally, it is contended that fair trade stifles price competition on the retail level; that competition among manufacturers is weakened; and that consumers are denied the economies of mass distribution. See, e.g., REPORT of THE ATTORNEY GENERAL's NATIONal Conmittee to Study the Antitrust Laws 153-54 (1955) ; Fulda, Resale Price Maintenancc, 21 U. CHI. L. REv. 175 (1954); Schachtman, Resale Price Maintenance and the Fair Trade Laws, 11 U. PitT. L. Rev. 562 (1950); Comment, 61 Yale L.J. 381 (1952). But cf. Adams, Resale Price Maintenance: Fact and Fancy, 64 Yade L.J. 967 (1955). The 
grounds. And Congress' exemption of fair trade from federal price-fixing laws does not necessarily constitute a federal endorsement of fair trade. ${ }^{36}$ However, these arguments are irrelevant. For wholly apart from the merits of fair trade as such, discriminatory enforcement of fair trade is an "unfair method of competition." 37 It permits manufacturers to misuse the privilege granted by the McGuire Act. And contrary to the FTC's second premise, the Commission would not have to compel a manufacturer to enforce fair trade in order to end this abuse. There is ample precedent for holding that a person who abuses an exemption from the antitrust laws thereby forfeits the privilege of the exemption. ${ }^{38}$

Rather than holding that a manufacturer who has enforced fair trade discriminatorily should be required to enforce it fully, the Federal Trade Commission should hold that the manufacturer has forfeited his right to use fair trade at all. Thus retailers would be free to lower their prices without fear of inducing a law suit by competing retailers. ${ }^{39}$ For the Commission order

FTC and the Department of Justice have frequently expressed their opposition to fair trade. FTC FAIR TRADE REPORT LIV-LXIV; House Antitrust Subcommittee Hearings, supra note 5 , at 18, 75; Senate Hearings on H.R. 5767, supra note 5 , at 12, 33.

36. When Congress enacted the McGuire bill it rejected the Keogh bill, H.R. 6925, \&2d Cong., $2 d$ Sess. (1952), because the latter would have been a federal endorsement of the principles of fair trade: it made violation of state fair trade laws "an act of unfair competition" actionable in the federal courts. See H.R. Rep. No. 1516, 82d Cong., 2d Sess. 50 (1952) ; Senate Hearings on H.R. 5767, supra note 5, at 322; 98 CoNG. REC. 4897, 4901, 4913, 4920,4937 (1952). The FTC interpreted this language as authorizing Commission action against violations of state fair trade laws, whereas no such action was implite by th: McGuire bill. $98 \mathrm{id}$. at 4900 . The Keogh bill was also criticized by some because it made discriminatory enforcement a "complete defense" to an injunction suit brought by a manufacturer against price-cutting retailers. $98 \mathrm{id}$. at 4937, 4940-41, 4954.

37. In Doubleday and Co., Docket No. 5897, 3 CCH TRADE REG. Rep. ๆf 25634 (FTC, Sept. 2,1955 ), the Commission held that a publisher who distributed his books through retailers subject to fair trade agreements, while permitting book clubs to distribute the same books at a lower price, had violated $\S 5$ of the FTC Act by discriminating between channels of distribution. Insofar as discriminatory enforcement favors discount houses over other retailers, see notes 9-18 supra and accompanying text, it seems to fit within the theory of the Doubleday case. However the Commission apparently felt that the jewelry retailers had failed to allege facts sufficient to indicate such discrimination. $1 \mathrm{CCH}$ TRADE REG. REP. If 3020.90, at 4130 (Feb. 21, 1955).

At any rate, even if discriminatory enforcement is not consciously used to prefer certain "channels," it is so closely related to violations of the Robinson-Patman Act that it clearly" falls within the category of "unfair methods of competition." See notes 45-54 infra and accompanying text; $c f$. Comment, 65 Y ALE L.J. 34 n.1 (1955).

38. E.g., United States v. Bausch \& Lomb Optical Co., 321 U.S. 707 (1944) (abuse of fair trade); United States v. Eastman Kodak Co., 1954 Trade Cas. f 67920, at 70006 (W.D.N.Y.) (same) ; Doubleday and Co., supra note 37. And, of course, the Commission can always proscribe the abuses. E.g., Univis Lens Co. v. United States, 316 U.S. 241 (1942) (abuse of fair trade and patents) ; Morton Salt Co. v. G. S. Suppiger Co., 314 U.S. 488 (1942) (abuse of patents); Charles Beseler Co., Docket No. 6328, 3 CCH Trade Reg. REP. If 25438 (FTC, April 25, 1955), consent order, 3 id. \ 25605 (FTC, July 12, 1955) (abuse of fair trade); cf. Note, 64 Y ALE L.J. 426, 432-33 (1955).

39. See notes 25-27 supra and accompanying text. 
would constitute a legal "abandonment" of fair trade by the manufacturers. It is true that such FTC action would pro tanto deny the advantages of fair trade to manufacturer and retailers. ${ }^{41}$ But the FTC order need not be permanent; it could bar fair trade for a stated period of time. ${ }^{42}$ After the period expired, fair trade could be resumed; that decision would lie with the manufacturer. But the manufacturer would resume fair trade under threat of heavy fines if he again discriminated in his enforcement. In fact, resumption could be conditioned on adherence to prescribed standards of enforcement. ${ }^{43}$ Such prescriptions would not constitute FTC endorsement of fair trade.44 Rather, they would be directed at preventing manufacturers from misusing fair trade in order to discriminate between competing customers.

A manufacturer who discriminatorily enforces his fair trade prices should also be subject to the provisions of the Robinson-Patman Act. ${ }^{45}$ RobinsonPatman was enacted to prevent mass distributors from using their market leverage to secure preferential treatment. ${ }^{46}$ Section 2(a) of the Act makes it illegal for sellers to discriminate between customers by charging unequal prices for like goods. ${ }^{47}$ Discriminatory enforcement of fair trade agreements would not come within this section if the fair-trading manufacturer charged the same price to each customer. ${ }^{48}$ However, enforcing fair trade contracts against some retailers but not against others is clearly a form of discrimination.

40. See note 27 sipra and accompanying text.

41. See notes 6-8 supra and accompanying text.

42. See United States v. Bausch \& Lomb Optical Co., 321 U.S. 707, 729 (1944) (fair trade agreements invalidated for a period of six months); United States v. Eastman Kodak Co., 1954 Trade Cas. If 67920, at 70006 (W.D.N.Y.) (defendant could request court fiermission to enter into fair trade agreements eight years after judgment).

43. The manufacturer might have to pay fines of $\$ 5000$ daily if he violated the FTC order. 52 Stat. 114 (1938), as amended, 15 U.S.C. $\$ 45(1)$ (1952).

4. Commissioner Mason described the FTC order in the Doubleday case proscribing discriminatory fair trading, see note 37 supra, as neither an endorsement nor condemnation of fair trade. He thought it told fair trade opponents and advocates, " A plague on both your houses.' " Doubleday and Co., Docket No. 5897, 3 CCH TRADE REg. ReP. If 25634, at 35681 (FTC Sept. 2, 1955) (dissenting opinion).

45. 49 STAT. 1526 (1936), 15 U.S.C. $\$ 13$ (1952), amending 38 STAT. 730 (1914).

46. See S. Rer. No. 1502, 74th Cong., 2d Sess. passim (1936) ; H.R. Rep. No. 2287, 74th Cong., 2d Sess. passin (1936) ; 80 Cong. Rec. 8111 (1936) (Congressman Patman); $\$ 0$ id. at 9416 (Congressman Utterback) ; FTC v. Morton Salt Co., 334 U.S. 37, $42-43$ (1948). The abuses which led to the enactment of the Robinson-Patman Act are set forth in FTC, Final Report on the Chain Store Investigation, S. Doc. No. 4, 74th Cong., 1st Sess. (1934). See, generally, Austin, Price Discrimination Under the Robinson-Patian Act (1953) ; Oppenhem, Price and Service Discrimination Ujuer the Robinson-Patman Act (1949); Pamian, The Robinson-Patman Act (1938).

47. 49 STAT. 1526 (1936), 15 U.S.C. $\$ 13(a)$ (1952). Price discrimination becomes illegal whenever its effect may be substantially to lessen competition between the favored customer and his competitors. Ibid. Discrimination between competing customers is generally sulficient per se to satisfy the injury requirement. See Comment, 65 Y ALE L.J. 34, 69-70 \& n.201 (1955), and authorities there cited.

48. Discount houses generally have not depended upon discriminatory discounts in price, but have based their operations on high-volume, low-profit sales. See note 16 sipra. 
And Robinson-Patman forbids more than overt price discrimination; it provides also that secretive methods of discrimination not reflected in price are illegal per se. ${ }^{49}$ Thus section $2(\mathrm{e})$ states that a manufacturer who furnishes services to one customer must make those services available to all customers on "proportionally equal terms." 50 By fair-trading, the manufacturer enables retailers to sell his product at a profit margin secure from price competition."1 When he does not enforce against price-cutters, these benefits of fair trade are not functionally available to all customers. A few courts may be reluctant to classify these benefits as "services." 52 However, the enforcement of fair trade prices against violators is itself a service to retailers which must be provided by the manufacturer, if at all, on proportionally equal terms. ${ }^{53}$ Thus discriminatory enforcement of fair trade by manufacturers violates both the policy and express terms of Robinson-Patman, and constitutes grounds for injunctive proceedings brought by federal authorities or private litigants directly under that Act. 54

Furthermore, the courts should revitalize the remedies available to disfavored retailers. Primarily, the injured retailer should be given a direct

49. " $[I] t$ shall be unlawful for any person to discriminate in favor of one purchaser ... of a commodity bought for resale ... by contracting to furnish or furnishing . . . any services or facilities connected with the ... sale, or offering for sale of such commodity so purchased upon terms not accorded to all purchasers on proportionally equal terms." 49 STAT. 1527 (1936), 15 U.S.C. $\$ 13(\mathrm{e})$ (1952).

Section $2(\mathrm{e})$, as well as (d), dealing similarly with sellers' payments for services rendered by buyers, was intended to strike at pseudo-"service" rebates given by manufacturers to large purchasers when no actual or commensurate service vas rendered. AustIN, op. cit. supra note 46 , at 2,110-12; OPPEN HETM, op. cit. supra note 46 , at 46 ; 80 Cong. Rec. 9418 (1936) (Congressman Utterback). Primarily directed at unvarranted advertising allowances, the sections were couched in general terms so as to provide for any ingenious substitutes. Ibid; Note, $50 \mathrm{HARv}$. L. Rev. 106, 114-15 (1936). Injury to competition need not be proved. Elizabeth Arden, Inc. v. FTC, 156 F.2d 132, 135 (2d Cir. 1946), cert. denied, 331 U.S. 806 (1947) ; Elizabeth Arden Sales Corp. v. Gus Blass Co., 150 F.2d 988, 995-96 (Sth Cir.), cert. denied, 326 U.S. 773 (1945) ; Corn Products Refining Co. v. FTC, 144 F.2d 211, 219 (7th Cir. 1944), aff'd, 324 U.S. 726 (1945). This per se construction has been severely criticized, Aussin, op. cit. supra, at 114-15, 120-21; Oppenheim, Federal Antitrust Legislation: Guideposts to a Revised National Antitrust Policy, 50 MICH. L. Rev. 1139, 1206-07 (1952), but per se proscription of unearned "service" rebates serves the purpose of encouraging sellers to bring rebates into the open.

50. See note 49 supra.

51. See note 10 supra and accompanying text.

52. The typical merchandising "services" previously questioned under $\S \S 2$ (d), (e) are listed in $1 \mathrm{CCH}$ TrADE REG. REP. III 3522.250-3522.426, 3524.140-3524.325 (10th ed. 1954) ; Austin, op. cit. supra note 46, at 112-13. Primarily, the sections were directed at advertising allowances. See note 49 supra. Thus a few courts may be unwilling to analogize the benefits of fair trade to these services.

53. See note 49 supra.

Alternatively, the non-enforcenient in favor of some discount houses may be the "service" by which the discrimination may be attacked.

54. Private litigants may sue sellers for violations of the Robinson-Patman Act and obtain treble damages or injunctive relief. 38 STAT. 731,737 (1914), 15 U.S.C. $\$ \$ 15,26$ 
right of action against the manufacturer, who has the power to enforce fair trade agreements and should have the responsibility of enforcing them fairly. The courts could base this right of action on the Robinson-Patman theory ;5s on the theory that discriminatory enforcement by the manufacturer is a common law tort against disfavored retailers $; 0$ or on the theory that the retailer is entitled to specific performance of a constructive condition in the fair trade contract that the manufacturer will provide comprehensive, or at least nondiscriminatory, enforcement against all violators. ${ }^{57}$ Under any of these theories, judicial relief could be a flexible and effective means of eliminating discrimination: the courts could prohibit the manufacturer from further fair trading ${ }^{\text {is }}$ or they could condition fair trading on the establishment of an effective enforcement program. ${ }^{59}$ Secondarily, the courts should not uncritically grant preliminary injunctions against retailers who choose to combat discriminatory enforcement by lowering their own prices. ${ }^{60}$ If a retailer alleges discriminatory enforcement by way of defense to a manufacturer's injunction suit, and supports his allegations with particularized affidavits, ${ }^{61}$ the courts should deny a preliminary injunction unless the manufacturer proves that he has a non-discriminatory enforcement program. ${ }^{62}$ Otherwise, the

(1952). Section 11 grants the FTC jurisdiction to enforce the Act. 38 STAT. 734 (1914), as amended, 15 U.S.C. $\$ 21$ (1952).

This theory never has been tested on its merits. In E. J. Korvette Co. v. Parker Pen Co., CCH Trade Reg. Rep. (1955 Trade Cas.) If 68034 (S.D.N.Y. April 23, 1955), the court dismissed a cornplaint alleging violations of $\$ \$ 2(\mathrm{c})$, (d), and (e) of Robinsonl'atman on procedural grounds. It held that the complaint should have been pleaded as a compulsory counterclaim under Federal Rule 13(a) in the manufacturer's previously instituted fair trade enforcement suit against the plaintiff, since both cases arose from the manufacturer's distribution system. However, the retailer successfully avoided the imposition of a preliminary injunction in the manufacturer's enforcement action by alleging discriminatory enforcement. Parker Pen Co. v. E. J. Korvette Co., CCH TrADE REg. Hep. (1955 Trade Cas.) If 68025 (S.D.N.Y. April 16, 1955). Cf. note 26 stura.

55. See text at notes 45-54 supra.

56. Cf. MicClunTock, EQUITY $\$ 151$ (2d ed. 1948) (discussing "unfair competition"); WaLsH, Eguitx $\$ \$ 44,47$ (1930) (same).

57. Cf. 3 CoRBIN, Contracts $\$ \$ 632,653-54$ (1951) (discussing the policy basis of judicial imposition of constructive conditions).

58. See notes 38,42 supra and accompanying text.

59. General Elec. Co. v. R. H. Macy \& Co., 199 Misc. 87, 99, 103 N.Y.S.2d 440, 452 (Sup. Ct. 1951) (injunction conditioned on continuance of vigorous enforcement program); Fishman v. Kaye, 1950-51 Trade Cas. $\{62718$ (N.J. Super. Ct. 1950) (defendant retailer may move to vacate injunction if within thirty days the plaintiff retailer or the manufacturer have not taken affirmative action against other violators).

60. See notes 23, 24 supra and accompanying text.

61. Some courts have held that the issues raised by the affidavits cannot be adequately resolved on an interim motion for a preliminary injunction, but require a full trial. Parker Pen Co. v. E. J. Korvette Co., CCH Trade Reg. ReP. \ 68025 (S.D.N.Y. April 16, 1955); Westinghouse Elec. Corp. v. Charles Appliances, Inc., 1954 Trade Cas. II $676 \$ 5$ (N.Y. Sup. Ct.).

62. Effective enforcement may be a difficult matter for the manufacturer to prove; fair trade may be inherently difficult to enforce. This would be especially true in states which have invalidated the non-signer provisions. See Comment, 61 YALE L.J. 381, 403 
granting of the injunction will often injure the retailer more than denial would injure the manufacturer. ${ }^{63}$

Discriminatory enforcement of fair trade prices should not be tolerated in states which have adopted a policy of favoring fair trade. Several theories, as yet unused, can be employed effectively to eliminate the discriminations. The only argument against utilizing these theories is that continuing discrimination might result in undermining. the foundations of fair trade. ${ }^{64}$ But this argument is misdirected. If fair trade is as undesirable a policy as most authorities now believe, the remedy is to attack it directly on its merits. For whether fair trade is undesirable or not, discriminatory enforcement so injures disfavored retailers that manufacturers should be required to enforce their prices fully or not at all.

(1952); note 34 supra. In some of these jurisdictions manufacturers have nevertheless been able to take enforcement action against non-signers on the theory that the nonsigner has induced a breach of contract by his supplier, who is a party to a fair trade contract with the manufacturer. Sce, e.g., Sunbeam Corp. v. Economy Distributing Co., 131 F. Supp. 791 (E.D. Mich. 1955) ; Sunbeam Corp. v. Payless Drug Stores, 113 F. Supp. 31 (N.D. Cal. 1953). However, some courts have held that to sustain such an action would violate the public policy of the state, since the non-signer provision has been held unconstitutional. Argus Cameras, Inc. v. Hall of Distributors, Inc., 72 N.W.2d 152 (Mich. 1955); Sunbeam Corp. v. Masters of Miami, Inc., 225 F.2d 191 (5th Cir. 1955). Moreover, even in non-signer states, mail order houses in non-fair trade states may ship goods into fair trade states at prices lower than the established price. See, generally, Comment, $22 \mathrm{U}$. CHr. I. REv. 525 (1955); Notes, 43 Geo. L.J. 258 (1955), 30 IND. L.J. 502 (1955). It is likely that all these difficulties are aggravated in a period when supplies of goods are plentiful. Corey, Fair Trade Pricing: A Reappraisal, Harv. Bus. Rev., Sept.-Oct. 1952, pp. 47, 61. The result is that it is costly to maintain an effective fair trade program. CLARK \& $\mathrm{CL}_{\mathrm{L} A R K}$, Princtples of Marketing 700 (3d ed. 1942); Note, 64 Harv. L. Rev. 1327, 1333-34 (1951) ; See General Elec. Co. v. S. Klein, Inc., 1953 Trade Cas. If 67443, at 606249 (N.Y. Sup. Ct.) (dictum). The costs and difficulties of enforcement have persuaded some manufacturers to cease fair trading. Time, Sept. 12, 1955, p. 103; 20 Consuners REP. 339, 340 (1955). Others, however, have increased their enforcement budget. Business Week, July 30,1955 , p. 54 .

Nevertheless, ineffective enforcement may seriously injure small retailers. See notes 19-27 supra and accompanying text. Therefore, courts should be convinced of the effectiveness of the enforcement program before granting injunctive relief. Reliable surveys may be used to determine the extent of fair trade violations and the promptness with which the manufacturer detects them and proceeds against them. See General Elec. Co. v. Federated Dep't Stores, Inc., CCH Trade REg. Rep. (1955 Trade Cas.) $\llbracket 68098$, at 70552-54 (E.D. Wis. July 20, 1955). The cost of enforcement may be considered a typical cost of preserving the value of a brand name. Cf. note 6 supra.

63. See General Elec. Co. v. Federated Dep't Stores, Inc., supra note 62, at 70557-58; notes 6, 19-27 supra and accompanying text.

64. Cf. Corey, supra note 62, at 59; Comment, 61 YALE L.J. 381, 403 (1952); see also Rowe, Price Discrimination, Competition, and Confusion: Another Look at RobinsonPatman, 60 Yale L.J. 929, 938-39 (1951).

This argument is difficult to evaluate. It may be that fair trade is inherently difficult to enforce, see note 62 supra, and that it would be more quickly undermined by legally requiring manufacturers to enforce it fully or not at all. Faced with the costs and diffculties of full enforcement, manufacturers would be likely to reappraise the utility of fair trade. Many might prefer to drop it rather than assume the added cost. 